\title{
ABOUT ISSUE 4 OF 2021
}

\begin{abstract}
his is the last issue of Access to Justice in Eastern Europe in 2021, a year of great expectations and challenges. A hybrid form of existence - online and offline occupies our lives, and we face a completely new reality. At the same time, this year is a year of great achievements, which I am delighted to share. The LithuanianPolish-Ukrainian team won the project 'Impact of the COVID-19 Pandemic on the Justice System. Case Study and Suggested Solutions', co-financed by the Polish National Agency for Academic Exchange within the Urgency Grants programme, which will be implemented next year. The main idea and focus of this project are to observe standards of access to court and implementation of the right to a fair trial in the period of the pandemic, transforming the main principles of civil procedure in the face of this challenge. Our excellent team consists of Katarzyna Gajda-Roszczynialska from the University of Silesia, Vigita Vebraite from Vilmius University, and me from Taras Shevchenko National University of Kyiv. We sincerely hope that together, we will contribute to current research and propose useful recommendations for possible future obstacles.
\end{abstract}

For me, it is also a great honour and delight to present this issue's contributions and briefly sketch an outline to draw attention to the themes. The issue opens with the article of Remco Van Rhee, who has played an important role in Ukrainian justice development in recent years through his participation in various projects and activities. This time, he turned his attention to mandatory mediation before litigation and the kaleidoscope of European best practices, providing a deep understanding of what mediation is and why it should be mandatory.

A fresh and interesting perspective on Polish-Ukrainian legal services was prepared by Stanisław Lipiec, a young researcher, who raised incredibly important issues of interrelations between Ukrainian and Polish legal advisers and made a prognosis regarding requests for legal services in both our states in the coming years.

The uncommon but important and interesting topic of Inna Boyko's research article is related to precedent in international adjudication. A deep analysis of international court decisions combined with theoretical approaches makes this study worth the attention of our readers.

The last research article, written by Olga Donets, concerned issues of natural resources and human rights. The pandemic has made us more aware of our relationship with the environment, and this article is a witness to the increasing interest of the scholarly community in issues of environmental rights protection in their entirety.

A few notes have also been included in this issue due to their interesting insights and importance for further research.

Finally, let me share some of our latest accomplishments. Please welcome the new managing editors in our team - Dr. Oksana Uhrynovska, PhD in Law, Assoc. Prof. of the Department of Civil Law and Procedure, Ivan Franko National University of Lviv, Ukraine, and Dr. Olena Terekh, PhD in Law, Assoc. Prof. of the Department of Civil Procedure, Law School, Taras Shevchenko National University of Kyiv, Ukraine. Managing editors are those who bear the burden of ensuring high-quality content. I am extremely proud of our team - the managing 
editors, the helpful Editorial Board members, the professional reviewers, and the kind language editors - who helped all of us share the authors' research with an international audience and attract more attention to the legal science of Eastern Europe and our reform, case-law, achievements, and problems.

The essence of the rule of law and equal access to justice should not be limited by any borders, and sharing results and best practices helps us to make our world sustainable, peaceful, and strong.

\section{Editor-in-Chief}

Prof. Iryna Izarova

Law School, Taras Shevchenko National University of Kyiv,

Ukraine 